\title{
Blogging for the Distance Librarian
}

\author{
Paul R. Pival
}

\begin{abstract}
Based on user lookups, Merriam-Webster Online proclaimed "Blog" the word of the year for 2004. ${ }^{1}$ Distance librarianship, until mid-way through 2004, was a subject that was underrepresented in the blogosphere. The inception of a blog called The Distant Librarian: Comments on the World of Distance Librarianship is chronicled in this article, along with suggestions for how and where to get started, as well as how to incorporate blogs that support library services for distance students. [Article copies available for a fee from The Haworth Document Delivery Service: 1-800-HAWORTH. E-mail address: $<$ docdelivery@haworthpress.com> Website: <http://www.HaworthPress.com> (0) 2005 by The Haworth Press, Inc. All rights reserved.]
\end{abstract}

KEYWORDS. Blogs, blogging, Web logs, Internet, aggregators

This article is primarily a personal account of how I started a blog called The Distant Librarian: Comments on the World of Distance Librarianship. ${ }^{2}$ The article will not be a discussion of the technical underpinnings of blogs; but rather a narrative of what I get out of blogging,

Paul R. Pival, MLS, is Distance Education Librarian, University of Calgary, 213E MLT, Calgary, Alberta, Canada T2N 1N4 (E-mail: ppival@ucalgary.ca).

Journal of Library \& Information Services in Distance Learning, Vol. 2(2) 2005

Available online at http://www.haworthpress.com/web/JLISD

(C) 2005 by The Haworth Press, Inc. All rights reserved.

doi:10.1300/J192v02n02_05 
and why you might want to get involved too, either as a consumer or producer.

While I had experimented with it before that, I began blogging regularly in April 2003 as a direct result of a presentation given by Bill Buxton, a designer and a researcher concerned with human aspects of technology and a big mountaineer. Much of his talk was about human computer interfaces, but then he began talking about his research on the history of mountaineering, and he showed us a Web page he had built to track his research. ${ }^{3}$ Although this page was certainly available to the world at large, being a Web site, Bill used it mostly to keep notes for himself; to help him remember and to link his thoughts. He mentioned that he always writes as he reads, and I thought that sounded like a pretty good way for my overtaxed mind to remember things it no longer did.

Bill's site is not a blog, but I thought the blog format would be easier to maintain and update, and I set off in search of a free service to experiment with. For my first personal blog, I ended up with Blogger, which is a great way to get started-free, very easy, with a good user community and a growing list of features. ${ }^{4}$ My first blog was (and still is) intended for me to annotate sites that I come across, or to leave notes for myself that I can always get back to. Pretty similar to File Uniform Resource Locators (FURL) in concept, but in a format that I find easier to use. Plus, I do not think FURL existed when I started, or at least I did not know about it then. FURL is a service that allows one to annotate bookmarks and store them on a public server, making them accessible from any connected computer rather than keeping one's bookmarks (usually non-annotated) only on one computer. ${ }^{5}$

Every time I came across a Web site or read an article I thought held a nugget I might want to recall at a later time, I would add it to my personal blog, with as long or short an annotation as I thought would help me remember why I put it there. Blogger has a bookmarklet that easily allows the posting of a Web site to any blog one manages through them, and an individual can use the bookmarklet whenever s/he wants to post a thought. With my blog, I now have a fragmented stream of consciousness for my professional (and sometimes personal) reading and thoughts going back almost two years. The very act of having posted something in my blog seems to lodge a tiny piece of string around the finger in my mind; enough to recall that there is something worth looking at in my blog on subject "x" when the need arises. Blogger has recently added a search tool as well, so it is easy to find something posted long ago. Think of it as a reference manager for thoughts, rather than for citations. This article is not meant to be a sell-job for Blogger or any 
other blogging service; it is just a brief account of how and why I got started.

For about a year, I ran the blog only for my personal edification, but I also read the blogs of librarians who were actually making regular contributions to the profession (at least for those of us reading their blogs). Reading those blogs provided me with a sense of connection and, eventually, inspiration. The information they posted was much timelier than anything found in the professional literature, and it usually came with a personal slant that made it particularly relevant (and again personal). I wanted to contribute too, but needed to find a niche. Technology was covered, as was general library news, and I am not one for thinking anyone else cares about my personal library life, but eventually I realized that nobody out there was blogging about distance librarianship!

Now, we already have the OFFCAMP Listserv, to which we all subscribe (right?), so why did I think the world needed another outlet for talking about distance librarianship? ${ }^{6}$ Well, I did not necessarily, but I did want to write about what I was finding and thinking in the field, and I certainly did not want to start posting random (though relevant) thoughts to the listserv, so, again, the self-publishing route seemed a good fit. If people wanted to check in on what I was writing they could, without having to curse me and stab at the delete button.

How are blogs different than listservs? Obviously, with listservs, e-mails are delivered to your inbox; blogs are not (usually). Listservs are not generally searchable by the world at large, and are not indexed by Google, so blogs potentially have a much larger audience. Along the same lines, aside from copying/pasting from one list to another, it is difficult to link or cross-pollinate with listservs. However, with blogs it is extremely simple to link from one site to another. It is, after all, another type of Web page. Similar to listservs though, there are two ways to use blogs. You can become an author (a blogger), or you can become a consumer (reader).

What has blogging done for me? I now seek out and read the library literature with a more critical eye, because I know I may be expressing my opinion in a public forum. When I am evaluating a piece of software or service, I give it a more rigorous run-through for the same reason. When I read other blogs, I consciously look for connections to the world of distance librarianship, rather than just taking the posting at face value. I also try not to let myself fall too far behind in my professional reading. It may be an imagined audience, but I do not want to let my readers down. 
On the other hand, having this audience, real or imagined, creates a little stress too! If a couple of days go by and I either do not have time to post, or just have not come across or come up with an idea I think is relevant or interesting enough to comment on, I start to worry that I am letting my audience down. A study from late 2003 estimated that, of all the blogs that had been created over the previous few years, two-thirds had been abandoned (no new posts in the previous two months). On the other hand, the study also found that the average blog is updated only once every fourteen days, so maybe I should not feel the pressure that I do. ${ }^{7}$ A more recent Pew Internet and American Life Project report also found that most bloggers update their blogs once a week or less. ${ }^{8}$

As I mentioned earlier, my initial software of choice was Blogger. When I decided to blog publicly, though, I ended up choosing TypePad over Blogger for a couple of reasons. ${ }^{9}$ First, TypePad provides some rudimentary statistics about how many people visit and what posts they are viewing. I thought I should have an idea of how useful my blog appeared to be, in order to help me decide if I should continue after a year or so. The other nice feature provided by TypePad is the ability to assign categories to posts and then to view only posts that were assigned to a particular category. The downside to TypePad is that it does cost a small amount annually, unlike Blogger, which is completely free.

What can blogging do to support your distant students? If you have a "what's new" section on your services-for-distance-students' Web page, you might consider managing that section with blogging software. All that the software (Web-based or desktop) does is to simplify and organize the posting process.

Lisa Nickel at the University of North Carolina at Charlotte uses Blogger to keep her distance students apprised of new products and services available to them, and Rebecca Hedreen, Distance Education Librarian at Southern Connecticut State University, also uses Blogger for her distance students, but in this instance, as a template to answer "Frequently Answered Questions." 10 In each case, the librarian has included a link from her homepage to her blog, which is hosted on another site.

While I still use Dreamweaver for any necessary editing on my traditional Web pages, I now use Blogger to post updates directly to the "News" section of my Library Connection homepage. It was quite simple to include the main page HTML as a template in Blogger and instruct it to post all updates wherever I indicated on the Library Connection homepage. I believe this has an advantage, as I only have to give my students one URL to visit. ${ }^{11}$ 
If you do not want to produce a blog, consider consuming. While I am not going to go into RSS in this article, if you are not using an aggregator of some sort to consume blogs, you are really missing out on a wonderful way to save yourself some time. In a nutshell, aggregators allow you to quickly and simultaneously scan the posting headlines/ subject-lines of any number of blogs. Aggregators can be programmed to visit blogs of interest several times per day and highlight any postings that are new. Instead of visiting five, ten, or dozens of blogs in succession to see if there is anything new, you simply visit your aggregator to see if there are new postings in any of your blogs, and if so, you can scan the headlines before deciding if you want to actually read any of the full postings. An aggregator can be thought of as a Web browser for blogs. I currently have 102 RSS feeds in my aggregator (not all library-related), and not counting reading and thinking time for the posts that are really interesting or relevant, it probably takes me less than fifteen minutes per day to scan and read all the new postings in all of those blogs. How long would it take you to visit 102 different blogs, determine if there is anything new, and then actually read the relevant posts? Longer than 15 minutes? Do yourself a favor and check out an aggregator. Steven Bell wrote a good introduction to RSS and aggregators in the September 2004 issue of Ex Libris. ${ }^{12}$ In addition, many bloggers I know who are just getting started do so with Bloglines, which claims to be "the most comprehensive, integrated service for searching, subscribing, publishing and sharing news feeds, blogs, and rich Web content."13

So, what would you consume? While there are not necessarily many blogs that speak specifically to distance librarianship (that is why I started mine-remember?), there are dozens that discuss librarianship, as well as dozens more that speak to learning technologies, information literacy, and just about anything else you can tie to distance librarianship. What follows are some suggested starting points. If you have been following blogs for a while, you probably already know about many of these, but if you are new to the whole idea, what follows is a list of good starting points for someone practicing in the field of distance librarianship. Some of them you may recognize just as Web sites (not blogs), but they all have the magic $R S S$ feed that will allow you to view them in your aggregator as well.

\section{- The Shifted Librarian ${ }^{14}$}

Jenny Levine is the Internet Development Specialist for the Suburban Library System outside of Chicago, and she is a wonderful advocate for blogging in general. She posts frequently, some- 
times several times per day, and does an excellent job of pointing out how current topics are particularly relevant in the library world. She seems to focus on what can make the world better for our patrons, usually involving technology in some way.

\section{- Librarian In Black ${ }^{15}$}

Sarah Houghton is the e-Services Librarian for Marin County Free Library in California, and she focuses her posts on items of interest to librarians who happen to be "techies" as well. This means any of us who happen to be involved in supporting technical issues with our users, as well as those of us interested in the latest gadgets, not necessarily library-related.

- The Kept-Up Academic Librarian ${ }^{16}$

As the title suggests, Steven J. Bell, Director of Gutman Library at Philadelphia University, attempts to scan the Web for information that will impact academic librarians in one way or another. Because so much of the impact is technology-related, much of what he writes is also of interest to distance librarians.

- Library Stuff 17

Similar in idea to the Kept-Up site above, Steven Cohen focuses on more than just academic librarianship in his "library weblog dedicated to resources for keeping current and professional development." Steven is a law librarian in New York, and is a very frequent poster.

- LIS News ${ }^{18}$

From the FAQ section of this site, an excellent description:

LISNews is a collaborative weblog [aka blog] devoted to current events and news in the world of Library and Information Science. A dedicated team of authors scours the Web to find stories they find interesting. You'll find links to interesting stories and Web sites, along with original stories, interviews and reviews. LISNews is updated frequently around the clock, usually 7 days a week. We are a non-commercial site, supported by our users.

This was a blog that I used to visit occasionally in my preaggregator days-now I can visit it whenever it is updated, and it only takes a few seconds. 
- Information Literacy Weblog19

With its authors based in the United Kingdom, this blog does a really good job of discussing information literacy outside of North America. It is good to be a global citizen! Primarily run by Sheila Webber, Bill Johnston, and Stuart Boon, the blog provides frequent mention of and postings from information literacy conferences around the world.

- Pew Internet and American Life Project ${ }^{20}$

This is the place to learn quickly about new reports related to this project. If your distance students are online, these reports will be relevant to you.

- OLDaily 21

Stephen Downes is a senior research officer with the National Research Council of Canada in Moncton, New Brunswick, Canada, and he has a long history in distance education. While this blog does not deal with libraries, it is one of the best covering the field of distance education, and thus should definitely be in your toolbox or aggregator.

- Online Learning Update 22

This is one of several blogs maintained by Ray Schroeder of the University of Illinois at Springfield, a Professor Emeritus of Communication and Director of Technology-Enhanced Learning.

- LIS Blogsource 23

Affiliated with the LIS News site mentioned above, this is a great place to find out about new library-related blogs. Updated fairly frequently.

- Leah in the Library ${ }^{24}$

Want a blast from the past, or a peek at what your library education might have consisted of had you been in school as a distance student today? Check out Leah in the Library-"A blog by Leah Signs, a girl just starting her MLIS through the distance program at the University of Washington."

If you cannot find a site that seems perfect for your eclectic needs, it is possible to create a completely customized $R S S$ feed through a service like PubSub. ${ }^{25}$ Based on the search terms you provide, $P u b S u b$ will cre- 
ate a feed for your aggregator that will gather posts from any of the over three million blogs it monitors. So, if you want to track whenever a blogger mentions your university, or even your library, PubSub will allow you to do so. Think of it as an automatic blog search-engine that delivers directly to your aggregator.

There is also some evidence of a pedagogical connection to blogging. Stephen Downes (of OLDaily mentioned above) wrote an excellent piece entitled, "Educational Blogging," in the September/October 2004 issue of Educause Review. ${ }^{26}$

Blogging has opened up a new form of personal-knowledge management for my professional life. Reading blogs allows me to keep up-to-date with the latest news and trends in librarianship (and other areas of personal interest). Producing a blog for the field of distance librarianship has forced me to read Web-based and paper literature with a more critical eye, and it has allowed me to make contact with likeminded librarians around the world. Maintaining a news-type blog specifically for my distance students allows me to easily provide timely and important information to my primary clientele. Perhaps blogs can do something similar for you.

\section{NOTES}

1. Merriam-Webster Online. Available at: http://m-w.com/info/04words.htm (Accessed November 30, 2004).

2. The Distant Librarian: Comments on the World of Distance Librarianship. Available at http://distlib.blogs.com (Accessed November 30, 2004).

3. Books on the History and Explortion of Central Asia, and the History of Climbing, and Mountaineering, Especially in the Himalaya and Karakoram Ranges. Available at: http://www.billbuxton.com/climbing.html (Accessed November 30, 2004).

4. Blogger. Available at: http://www.blogger.com (Accessed November 30, 2004).

5. FURL-Your Personal Web. Available at: http://www.furl.net (Accessed November 30, 2004).

6 . For access to the archives, as well as information on how to join or leave the list, see Archives of OFFCAMP. Available at: http://listserv.utk.edu/archives/offcamp. html (Accessed November 30, 2004).

7. "Perseus Blog Survey." Available at: http://www.perseus.com/blogsurvey/ thebloggingiceberg.html (Accessed November 30, 2004).

8. Amanda Lenhart, John Horrigan, and Deborah Fallows, Content Creation Online (Pew Internet and American Life Project, February 29, 2004). Available at: http://www.pewinternet.org/pdfs/PIP_Content_Creation_Report.pdf (Accessed November 30, 2004).

9. TypePad: Personal Web Logging Service. Available at: http://www.typepad. com (Accessed November 30, 2004). 
10. Distance Education Library Services at Atkins Library. Available at: http:// distanceedlibrarian.blogspot.com/ (Accessed November 30, 2004); Frequently Answered Questions. Available at: http://frequanq.blogspot.com/ (Accessed November 30, 2004).

11. Library Connection: Library Services for Distance Students. Available at: http://www.ucalgary.ca/library/libcon/ (Accessed November 30, 2004).

12. Steven J. Bell, "RSS and News Aggregators: What Do You Really Need to Keep Up?” Ex Libris 189 (September 5, 2003). Available at: http://marylaine.com/exlibris/ xlib189.html (Accessed November 30, 2004).

13. Bloglines. Available at: http://www.bloglines.com (Accessed November 30, 2004).

14. The Shifted Librarian: Shifting Libraries at the Speed of Byte. Available at: http://www.theshiftedlibrarian.com/ (Accessed November 30, 2004).

15. Librarian in Black: Resources and Discussions for the "Tech-Librariansby-Default" among Us. Available at: http://librarianinblack.typepad.com/ (Accessed November 30, 2004).

16. The Kept-Up Academic Librarian: Helping Academic Librarians "Keep Up" with News and Developments in Higher Education. Available at: http://keptup.typepad. com/academic/ (Accessed November 30, 2004).

17. Library Stuff. Available at: http://www.librarystuff.net/ (Accessed November 30, 2004).

18. LIS News: Librarian and Information Science News. Available at: http:// www.lisnews.com/ (Accessed November 30, 2004).

19. Information Literacy Weblog: Sharing Relevant Items and Information Relating to Information Literacy Worldwide. Available at: http://ciquest.shef.ac.uk/infolit/ (Accessed November 30, 2004).

20. PEW Internet and American Life Project. Available at: http://www.pewinternet. org/ (Accessed November 30, 2004).

21. OLDaily. Available at: http://www.downes.ca/news/OLDaily.htm (Accessed November 30, 2004).

22. Online Learning Update. Available at: http://people.uis.edu/rschr1/onlinelearning/ blogger.html (Accessed November 30, 2004).

23. LIS Blogsource: The Library Weblog about Library Weblogs. Available at: http://www.lisblogsource.net (Accessed November 30, 2004).

24. Leah in the Library. Available at: http//leahinthelibrary.library-blogs.net/ (Accessed November 30, 2004).

25. PubSub. Available at: http//www.pubsub.com/ (Accessed November 30, 2004).

26. Stephen Downes, "Educational Blogging," Educause Review 9 (September/October 2004): 14-16, 18, 20-22, 24, 26. Available at: http://www.educause.edu/pub/er/ erm04/erm0450.asp (Accessed November 30, 2004).

Received: October 14, 2004

Reviewed November 24, 2004

Revised and Accepted: December 7, 2004 